\title{
Examinations on the relationship between claw health and the assessment of housing conditions based on a welfare index and critical checkpoints
}

\author{
Silke Heinz', Norbert Kanswohl' and Anke Römer² \\ 'Department of Agricultural Technology and Process Engineering, Faculty of Agricultural and Environmental Sciences, \\ University of Rostock, Rostock, Germany, ${ }^{2}$ Institute for Animal Production, State Institute for Agriculture and Fishery \\ MV, Dummerstorf, Germany
}

\begin{abstract}
Aim of the present study was to examine the relationship between the herd status for claw health and herd parameters. Herd parameters were derived from an assessment of the housing conditions and were based on a welfare index and critical checkpoints. Data has been collected on four conventional large dairy farms in northeast Germany. All farms have free-stall systems with cubicles offering a lying area. During the period from 2005 to 2008 on each farm claw disorders were recorded at time of regular hoof trimming, i.e. two or three times a year. Data was augmented by data on veterinary treatments of feet and legs. The Data comprises 18119 observations of 3690 cows. Housing conditions were assessed in the year 2008. The results show that a consequent and determined management of herd health is necessary to substantially improve the status of claw health. Housing and management confirming the rules of animal welfare will contribute to the well-being of dairy cows.
\end{abstract}

Keywords: dairy cattle, cow comfort, claw health, animal welfare, housing conditions

\section{Zusammenfassung}

\section{Untersuchungen zum Zusammenhang zwischen der Klauengesundheit und der Beurteilung von Haltungsbedingungen unter Anwendung des Tiergerechtheitsindexes und der kritischen Kontrollpunkte}

Ziel der vorliegenden Untersuchung war es, Zusammenhänge zwischen der Entwicklung der Klauengesundheit und dem Niveau voneinander abweichender Haltungsbedingungen zu analysieren. Die Beurteilung der betriebsspezifischen Haltungsbedingungen erfolgte auf der Grundlage des Tiergerechtheitsindexes und der kritischen Kontrollpunkte. Es wurden vier konventionell wirtschaftende Milchviehbetriebe in Nordostdeutschland ausgewählt, deren Kühe in Liegeboxen-Laufställen gehalten wurden. Die Klauengesundheitsdaten umfassten sowohl Befunde von der 2- bzw. 3-mal jährlich durchgeführten professionellen Klauenpflege als auch alle betriebsinternen Aufzeichnungen zu zwischenzeitlich akuten Klauenbehandlungen. Über den Zeitraum von 2005 bis 2008 wurden 18119 Datensätze zur Klauengesundheit von 3690 Kühen erhoben und analysiert. Die differenzierten Haltungsbedingungen wurden für das Jahr 2008 ermittelt und hinsichtlich deren Tiergerechtheit beurteilt. Die Ergebnisse zeigen, dass durch ein konsequentes und 
zielorientiertes Handeln seitens des Herden- und Gesundheitsmanagements im jeweiligen Milchviehbetrieb eine gute Klauengesundheit aufrechterhalten und das Wohlbefinden der Milchkühe durch tiergerechte Haltungsbedingungen gesichert werden kann.

Schlüsselwörter: Milchkühe, Kuhkomfort, Klauengesundheit, Tiergerechtheit, Haltungsbedingungen

\section{Introduction}

Claw lesions of dairy cattle are present worldwide. The information about lameness in dairy cattle varied during the last 10 years considerably. Alban (1995) reported a lesion rate of 7\%, Whay et al. (2002) analysed $22 \%$ and Somers et al. (2003) even $80 \%$. In Germany claws and leg disorders are the third most culling reasons in the year 2009 with 12.3\% (VIT 2010). In spite of improvements in housing conditions of dairy cattle there are occurred claw lesions which are an indicator for discrepancies between the claims of animals and the offered housing conditions. Claw lesions are multifactorial and complex in their origin. According to Mülling (2004) housing conditions have direct and indirect effects on claw health, e.g. lying surface (Tucker et al. 2003), walking area (Vanegas et al. 2006) and hoof trimming (Manske et al. 2002). The high percentage of animals with claw disorders has also an influence on the longevity (productive life) of high-yielding dairy cows. Nowadays longevity is shorter than the duration up to the achievement of the breed specific peak value of milk yield (Warnick et al. 2001, Booth et al. 2004). König \& Landmann (2007) confirmed that the age structure in dairy herds worsened in the Holstein population during the last years. Hare et al. (2006) determined a productive herd life of dairy cattle in the USA from 28 to 36 months. According to VIT (2010) dairy cows reach their highest milking yield approximately in the third lactation. Therefore genetic milk potential of cows is still used incompletely. On the other hand low longevity is contra productive from an economic point of view. Wangler (2007) determined that a dairy cow had to reach at least the third lactation to be effective. Besides, claw lesions cause additional costs up to $600 €$ per lameness (Mülling 2004). At the same time consumers look for milk products produced of raw milk from healthy and well-housed animals (Steiger 2000).

In this context the improvement of claw health by welfare housing conditions for animals and a management in accordance with animal health and efficient milk production are of high relevance.

Based on this situation four large conventional dairy farms with cubicle housing systems were selected to analyse and assess relationships between the development of claw health and the level of different housing conditions. A more comprehensive inclusion of housing parameters with regard to physiological functional areas and human-animal relationships (management) within the farm comparisons was applied. 


\section{Material and methods}

\section{Material}

For analysis objects four conventional large dairy farms in northeast Germany were selected. The breed of all dairy cows was German Holstein and the cows were kept in free-stall systems with cubicles offering a lying area. The study was conducted from 2005 to 2008.

\section{Claw health}

Claw disorders of all cows were recorded at time of regular and professional hoof trimming, i.e. two or three times a year on each farm. Data was augmented by data on veterinary treatments of feet and legs. Taxonomy of claw lesions are based on the obligatory DLGdiagnosis key for claws and limbs lesions (Fiedler 2004). Data comprised 18119 observations from 3690 cows. Because of the analysed frequencies the following claw disorders were included in the study: laminitis, dermatitis digitalis, sole ulcer and tylom.

\section{Housing conditions}

Data of essential housing conditions were collected with a self-created check list. The check-list was structured equally in farm data, health data, animal physiological areas and human-animal relationships to guarantee the compatibility of housing conditions. Housing conditions were assessed in the year 2008.

\section{Methods}

Data preparation and combination occurred through data linking of single files by Access 2002 (Microsoft 2001a) and Excel 2002 (Microsoft 2001b). For data evaluation SAS 9.1.3 (SAS Institute Inc. 2003) and Microsoft Excel 2002 were used.

\section{Claw health}

Data sets on claw health were classified in a uniform structure: farm, measure, year and claw findings. The last ones were divided into »0« (without a claw lesion) and »1« (with a claw lesion) and were assigned to the four chosen claw lesions.

The various numbers of claw trimming and the different appearances of claw lesions per farm and year required a uniform inquiry basis for the number of findings. The annual average number of findings for each farm was calculated from the arithmetic average of the claw trimming data plus the findings recorded within the claw trimming intervals.

To compare the claw health development of these four farms, a ranking by rating the claw disorders with a place number (value area of 1 ... 4) was developed. The smaller this place number in comparison to another farm, the higher is the claw health status.

By using multiple logistic regression odds ratios were determined for the risk of the appearance of laminitis, dermatitis digitalis, sole ulcer and tylom. With the WALD-test was used to check $(P \leq 0.05)$ the influence of farm, year or number of claw trimmings per year.

The model equation for the inquiry of the odds ratios is: 


$$
Y_{i j}=\log [p / 1-p]=\mu+\beta_{i}+\beta_{j}+\varepsilon_{i j}
$$

where $Y_{i j}$ is the laminitis, dermatitis digitalis, sole ulcer or tylom, $p$ is the risk likelihood for a claw lesion, $\mu$ is the intercept, $\beta_{i}$ is the claw trimmings per year $(2005,2006,2007,2008), \beta_{j}$ is the farm $(\mathrm{I}, \mathrm{II}, \mathrm{III}, \mathrm{IV})$ and $\varepsilon_{i j}$ is the residual error.

\section{Housing conditions:}

The information and parameters from the check lists regarding to essential components of housing conditions were the basis for assessing farm levels.

A model was developed that is based on the procedures of the welfare index (TGI) according to Sundrum et al. (1994) and on the concept of critical checkpoints (CCP) according to Sanftleben et al. (2007). In this model housing components from the animal physiological functional area as well as signs from the CCP-complexes were included. The comparison of the different evaluations on the farms was equal to the methodical approach with claw health by rating with place numbers. Whereas the CCP-complexes were assessed descriptive, the point assessment for functional areas occurred through a comparison with minimum or reference values following the protection guideline for dairy cattle of the Lower Saxony (Nds. MELVL 2007). The arithmetic average for dimensions of the functional areas was included in this evaluation, to have an equivalent consideration for the CCP-complexes in the whole ranking.

According to the mathematical construct of the model the farm-related place number calculates itself as an average from:

$$
P N n_{i} \ldots=\left(\Sigma \bar{x}_{n, i}+\sum x_{m, i}\right) / 8
$$

where $n$ is the number of functional areas $(1,2,3), m$ is the number of CCP-complexes $(1,2$, $3,4,5)$.

The farm-related place number quantifies the well-being of housing conditions for each farm i as an indirect basis factor. It states: The smaller this size of a farm in comparison with another farm the more well-being the housing conditions are to be assess. It characterises the assessment in the conclusion »better than/worse than«.

\section{Results}

Table 1 shows the percentage of cows with claw lesions by farm, diagnosis and year. It is to consider that this is not the percentage of lame cows of a herd. By recording claw health during hoof trimming, smallest lesions were also documented. Farm I had the lowest percentages of claw-damaged cows by diagnoses: laminitis (9.6\%), dermatitis digitalis $(11.2 \%)$ and tylom $(4.2 \%)$. The lowest percentage of cows with sole ulcers was identified in farm III with $14.4 \%$, followed by farm I with $14.9 \%$. Compared to farm I and farm III, farm II and farm IV had higher percentages of cows with claw lesions. Their high percentages of cows with dermatitis digitalis (farm II: $25.5 \%$; farm IV: $44.8 \%$ ), laminitis (farm IV: $25.3 \%$ ) as well as sole ulcers (farm II: $20.9 \%$ ) are striking. 
Table 1

Percentage of claw lesions in dairy cattle by farm, diagnosis and year

\begin{tabular}{|c|c|c|c|c|c|c|}
\hline \multirow[t]{2}{*}{ Farm } & \multirow[t]{2}{*}{ Diagnosis } & \multicolumn{5}{|c|}{ Percentage of claw-damaged cows, $\%$} \\
\hline & & 2005 & 2006 & 2007 & 2008 & $\bar{x}$ \\
\hline \multirow[t]{4}{*}{ I } & laminitis & 8.9 & 17.2 & 8.1 & 4.3 & 9.6 \\
\hline & dermatitis digitalis & 14.8 & 11.5 & 16.2 & 2.3 & 11.2 \\
\hline & sole ulcer & 15.9 & 16.7 & 19.3 & 7.8 & 14.9 \\
\hline & tylom & 4.4 & 4.4 & 4.2 & 3.7 & 4.2 \\
\hline \multirow[t]{4}{*}{ II } & laminitis & 19.2 & 22.0 & 8.8 & 15.7 & 16.4 \\
\hline & dermatitis digitalis & 27.9 & 32.2 & 23.9 & 17.9 & 25.5 \\
\hline & sole ulcer & 15.0 & 27.0 & 20.3 & 21.5 & 20.9 \\
\hline & tylom & 6.7 & 10.4 & 8.4 & 7.9 & 8.4 \\
\hline \multirow[t]{4}{*}{ III } & laminitis & - & 10.5 & 9.0 & 19.8 & 13.1 \\
\hline & dermatitis digitalis & - & 18.3 & 7.4 & 11.3 & 12.3 \\
\hline & sole ulcer & - & 16.1 & 12.4 & 14.7 & 14.4 \\
\hline & tylom & - & 10.3 & 8.0 & 7.1 & 8.4 \\
\hline \multirow[t]{4}{*}{ IV } & laminitis & - & 24.1 & 25.2 & 26.6 & 25.3 \\
\hline & dermatitis digitalis & - & 32.9 & 40.8 & 60.8 & 44.8 \\
\hline & sole ulcer & - & 17.1 & 13.6 & 18.1 & 16.3 \\
\hline & tylom & - & 5.4 & 9.9 & 12.0 & 9.1 \\
\hline
\end{tabular}

Based on these results a place number rating was carried out for each claw disorder and farm (Table 2). Following decreasing farm order (F) for claw lesions was determined: laminitis $F \mathrm{~K}<\mathrm{F}$

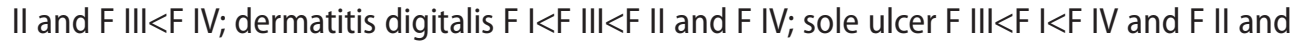
with tylom $F \mathrm{I}<\mathrm{F} \mathrm{III} \mathrm{as} \mathrm{well} \mathrm{as} \mathrm{F} \mathrm{II} \mathrm{and} \mathrm{F} \mathrm{IV.} \mathrm{In} \mathrm{the} \mathrm{result} \mathrm{of} \mathrm{this} \mathrm{evaluation} \mathrm{an} \mathrm{average} \mathrm{level} \mathrm{of}$ claw health was derived in the order: F I $>\mathrm{F}$ III $>\mathrm{F} \mathrm{II}$ and F IV.

Table 2

Ranking for claw lesions in dairy cattle by farm, diagnosis and year

\begin{tabular}{lcccccc}
\hline Diagnosis & Farm & \multicolumn{3}{c}{ Year } & \multicolumn{3}{c}{ Rating } \\
& & 2006 & 2007 & 2008 & EPoints & Place number \\
\hline Laminitis & I & 2 & 1 & 1 & 4 & 1.3 \\
& II & 3 & 2 & 2 & 7 & 2.3 \\
& III & 1 & 3 & 3 & 7 & 2.3 \\
\multirow{3}{*}{ Dermatitis digitalis } & IV & 4 & 4 & 4 & 12 & 4.0 \\
& I & 1 & 2 & 1 & 4 & 1.3 \\
& II & 3 & 3 & 3 & 9 & 3.0 \\
\multirow{3}{*}{ Sole ulcer } & III & 2 & 1 & 2 & 5 & 1.7 \\
& IV & 4 & 4 & 4 & 12 & 4.0 \\
& I & 2 & 3 & 1 & 6 & 2.0 \\
Tylom & II & 4 & 4 & 4 & 12 & 4.0 \\
& III & 1 & 1 & 2 & 4 & 1.3 \\
& IV & 3 & 2 & 3 & 8 & 2.7 \\
& I & 1 & 1 & 1 & 3 & 1.0 \\
& II & 4 & 3 & 3 & 10 & 3.3 \\
& III & 3 & 2 & 2 & 7 & 2.3 \\
& IV & 2 & 4 & 4 & 10 & 3.3 \\
\hline
\end{tabular}


Table 3 contains calculated odds ratios (OR) for the comparison of farms to the appearance of claw lesions. For laminitis there are significantly lower risks on farm I than in farms II to IV. Farm II showed a higher risk $(\mathrm{OR}=1.49)$ compared to farm III and a significantly lower risk $(\mathrm{OR}=0.48)$ compared to farm IV. Farm III had a significantly lower risk compared to farm IV $(\mathrm{OR}=0.32)$. For dermatitis digitalis farm I also shows lower risks compared to farm II to IV. Meanwhile, farm II had a higher risk compared to farm III $(\mathrm{OR}=1.99)$ and a lower risk in comparison to farm IV (OR=0.35). On farm III a lower risk was found compared to farm IV with an OR of 0.18 . With sole ulcers a lower risk was determined for farm I compared to farm II $(\mathrm{OR}=0.47)$ and IV (0.52) and compared to farm III by 1.03 . Therefore, there are no differences between farms I and III for housing conditions which favour the genesis of sole ulcers. Farm II had a higher risk for sole ulcers compared to farm III and IV while farm III $(\mathrm{OR}=0.50)$ showed a lower risk in comparison to farm IV. For tylom was determined a significantly lower risk for farm I in comparison with all other farms and for farm II compared to farm IV $(O R=0.74)$ as well as farm III compared to farm IV (OR=0.54). For the comparison of farm II with III an OR of 1.37 was calculated.

Table 3

Odds Ratios and confidence intervals for risk comparison of claw lesions by farms

\begin{tabular}{|c|c|c|c|c|}
\hline \multirow[t]{2}{*}{ Diagnosis } & \multirow[t]{2}{*}{ Farm } & \multirow[t]{2}{*}{ OR } & \multicolumn{2}{|c|}{ Confidence intervals } \\
\hline & & & Lower limit & Upper limit \\
\hline \multirow[t]{6}{*}{ Laminitis } & | compared with II & $0.38^{*}$ & 0.33 & 0.45 \\
\hline & I compared with III & $0.57^{*}$ & 0.49 & 0.66 \\
\hline & I compared with IV & $0.18^{*}$ & 0.16 & 0.21 \\
\hline & II compared with III & $1.49 *$ & 1.32 & 1.68 \\
\hline & II compared with IV & $0.48^{*}$ & 0.42 & 0.54 \\
\hline & III compared with IV & $0.32^{*}$ & 0.28 & 0.36 \\
\hline \multirow[t]{6}{*}{ Dermatitis digitalis } & | compared with || & $0.30 *$ & 0.26 & 0.34 \\
\hline & | compared with III & $0.59^{*}$ & 0.51 & 0.67 \\
\hline & I compared with IV & $0.10^{*}$ & 0.09 & 0.12 \\
\hline & II compared with III & $1.99 *$ & 1.78 & 2.21 \\
\hline & II compared with IV & $0.35^{*}$ & 0.32 & 0.39 \\
\hline & III compared with IV & $0.18^{*}$ & 0.16 & 0.20 \\
\hline \multirow[t]{6}{*}{ Sole ulcer } & | compared with || & $0.47^{*}$ & 0.41 & 0.53 \\
\hline & | compared with III & 1.03 & 0.90 & 1.19 \\
\hline & I compared with IV & $0.52^{*}$ & 0.45 & 0.60 \\
\hline & II compared with III & $2.21^{*}$ & 1.96 & 2.48 \\
\hline & II compared with IV & 1.10 & 0.71 & 1.25 \\
\hline & III compared with IV & $0.50^{*}$ & 0.44 & 0.57 \\
\hline \multirow[t]{6}{*}{ Tylom } & | compared with || & $0.44^{*}$ & 0.36 & 0.55 \\
\hline & | compared with |II & $0.61^{*}$ & 0.49 & 0.75 \\
\hline & I compared with IV & $0.33^{*}$ & 0.26 & 0.41 \\
\hline & II compared with III & $1.37^{*}$ & 1.16 & 1.62 \\
\hline & II compared with IV & $0.74^{*}$ & 0.62 & 0.88 \\
\hline & III compared with IV & $0.54^{*}$ & 0.45 & 0.64 \\
\hline
\end{tabular}

${ }^{*} P \leq 0.05$

Table 4 illustrates the construct of the evaluation model for housing conditions. The allocation of place numbers using the example of cubicle width was carried out on the basis of the following criteria: In farms I and IV the cubicle widths in each case were $1.20 \mathrm{~m}$. This width 
corresponded to the minimum of reference values according to the protection guideline for dairy cattle of the Lower Saxony (Nds. MELV 2007). Therefore these farms were valued with »1《. On farms III and II the widths of cubicles were only $1.10 \mathrm{~m}$ or $1.00 \mathrm{~m}$, respectively. Therefore, they fulfilled insufficiently the requirements for a welfare dairy farming. So the widths on farm III were valued with place number »3« and on farm II with »4«. The place numbers for included parameters were determined in the same way. As a result of the housing conditions assessment the lying and walking area on farm I were valued as the more well-being ones for dairy cattle compared to those on farms II to IV. For the feeding area and drinking water supply the following decreasing order was determined: farm I and III, followed by farm IV and II. The three times professional hoof trimming per year on farm I was assessed higher in comparison with two times claw trimming on farms II to IV. The animal monitoring was carried out daily on all farms.

Table 4

Ranking for housing conditions in 2008

\begin{tabular}{|c|c|c|c|c|c|}
\hline \multirow{2}{*}{$\begin{array}{l}\text { Functional circle/ } \\
\text { CCP-complex }\end{array}$} & \multirow[t]{2}{*}{ Parameter } & \multicolumn{4}{|c|}{ Place number of farm } \\
\hline & & 1 & II & III & IV \\
\hline \multirow[t]{7}{*}{ Lying area } & • cubicle length & 2 & 4 & 2 & 2 \\
\hline & - really useful cubicle length & 1 & 1 & 4 & 3 \\
\hline & - cubicle width & 1 & 4 & 3 & 1 \\
\hline & • neck rail curb & 3 & 1 & 4 & 1 \\
\hline & • head-zone-depth & 1 & 4 & 2 & 3 \\
\hline & - animal-lying-place-proportion & 1 & 3 & 3 & 3 \\
\hline & & 1.5 & 2.8 & 3.0 & 1.8 \\
\hline \multirow[t]{2}{*}{-CCP-complex } & - quality and care of the cubicle surface & - & - & - & - \\
\hline & & 1 & 4 & 2 & 3 \\
\hline \multirow[t]{4}{*}{ Walking area } & • walking area width & 1 & 4 & 1 & 1 \\
\hline & - width feeding and drinking place & 1 & 3 & 1 & 3 \\
\hline & • walking area/animal & 1 & 4 & 1 & 1 \\
\hline & & 1.0 & 3.7 & 1.0 & 1.7 \\
\hline \multirow[t]{2}{*}{ - CCP-complex } & - quality and care of walking area & - & - & - & - \\
\hline & & 1 & 4 & 2 & 3 \\
\hline Feeding area/ & - feeding place width/animal & 4 & 1 & 3 & 2 \\
\hline drinking water supply & • feed bunk length/animal & 1 & 3 & 3 & 2 \\
\hline \multirow[t]{2}{*}{ - dimensions } & - animal-feeding place-proportion & 1 & 1 & 4 & 1 \\
\hline & & 2.0 & 1.7 & 3.3 & 1.7 \\
\hline \multirow[t]{2}{*}{-CCP-complex } & $\begin{array}{l}\text { - control/cleaning of feeding area/ } \\
\text { drinking water supply }\end{array}$ & - & - & - & - \\
\hline & & 1 & 4 & 1 & 3 \\
\hline \multirow{2}{*}{$\begin{array}{l}\text { Functional circle claw } \\
\text { trimming/animal monitoring }\end{array}$} & - animal monitoring/day & 1 & 1 & 1 & 1 \\
\hline & - claw trimming/animal and year & 1 & 2 & 2 & 2 \\
\hline & & 1 & 2 & 2 & 2 \\
\hline \multirow[t]{2}{*}{ CCP-complex } & - barn climate and -hygiene & - & - & - & - \\
\hline & & 1 & 4 & 1 & 3 \\
\hline Place number $\left(\mathrm{PN}_{\mathrm{i}}\right)$ & & 1.2 & 3.3 & 1.9 & 2.4 \\
\hline
\end{tabular}


The place numbers for the functional areas and CCP-complexes assessment refer to the fact that farm I had more suitable welfare housing conditions compared with farms II to IV. For farm I a place number of 1.2 was determined. This was the comparatively highest level (2008) with regard to the well-being of dairy farming followed by farm III (1.9), farm IV (2.4) and farm II (3.3).

\section{Discussion}

In spite of numerous analyses for elaborating methods/procedures of collection and evaluation of well-being housing conditions (e.g. Sundrum et al. 1994, Sanftleben et al. 2007) there is still no practicable manageable procedure, which considers the housing conditions of cubicle housing systems for dairy cattle extensively. The problem can be seen in the requirement of more detailed knowledge about the combination of essential housing parameters and their intensities (Waiblinger et al. 2001, Eilers 2008).

The applied connection of the contentwise approaches of TGI and CCP-complexes were conducted with the purpose to combine predominantly structurally housing parameters of the TGI with the more extensive management parameters of the CCP-complexes. So, a comprehensive evaluation and assessment basis for the welfare of housing conditions is guaranteed. This combination is based on a rating by points because there are no accepted scores for the included qualitative and quantitative parameters and their elevation and assessment so far. An evaluation of qualitative parameters is only possible by their descriptive assessment.

The place numbers also refer to the following question: Which housing parameter is fulfilled, better or worse, in a farm in comparison with another farm? Ranking by place numbers allows statements about which farm housing conditions are more suitable for welfare compared to other farms.

The results confirm how important the designing of welfare housing conditions is and that this can reduce the risk of cows for claw lesions substantially. It was determined that the risk for claw lesions was lower on solid concrete flooring with deep bedded cubicles (farm I and III) in comparison to concrete slatted flooring with high cubicles (farm II and IV). Bergsten (2001) and Hultgren (2001) confirmed that cows on concrete solid flooring have significantly more claw lesions. On farm III the floorings were covered with rubber mats, what affected in particular the claw lesion sole ulcer positively. Manske (2002) determined a lower incidence of sole ulcers on rubber mats. Kremer et al. (2007) established more sole ulcers on elastic slatted flooring compared with concrete solid slatted flooring. Benz (2007) refers to the fact, that infectious claw lesions can be hardly influenced by elastic layers. Samel (2005) could not find differences in incidence of individual claw lesions between cows on elastic and concrete flooring. Koberg et al. (1989) referred to the fact that on concrete slatted flooring are more sole ulcers and infectious claw lesions while smooth flooring and rubber surfaces can be seen all together as a positive contribution to welfare farming. Kremer et al. (2006) investigated a higher activity level for cows on elastic flooring. Cook (2008) recommended the use of elastic layers in areas where animals have to stay or rest a longer time (e.g. feeding area). A frequent manure interval is also necessary for increasing the cleanliness of animals and improving the status of claw health (Steiner \& Keck 2000). This was achieved on farms I and III by a 
higher folding dung scraper frequency. Lying area management on farms I and III aimed on the fact, that animals could exercise their lying behaviour in a well-being way. Besides the observance of essential cubicle measurements the deep bedded cubicles were cleaned daily and were interspersed in a 2-daily rhythm. On farm II and IV the high cubicles were not interspersed. This could be impact negatively the cow's acceptance for these cubicles and led them to an increased standing position and walking. Thereby a higher claw pressure can favour the development of claw lesions. Siebenhaar et al. (2007) determined that elastic mats in high cubicles are also subjected to a successive decrease in use value. In this context Wolf (2000) stated, that there is no »best « lying mat because finally the conditions of each farm are relevant for the choice of the respective mat type. Kanswohl et al. (2006) confirmed that the daily cubicle care is more important than cubicle type and litter. Besides the structural condition the daily animal monitoring and the professional functional claw trimming have an essential influence on the claw health of dairy cattle. The results verify that three times claw trimming per year (farm I) can affect the status of claw health positively compared with two times claw trimming (farm from II to IV). There are still different opinions about the frequency of claw trimming for free-stall systems with cubicles. Stanek (2005) and Manske et al. (2002) named a half-yearly correction as »optimum« while Kremer (2008) pleaded for three times hoof trimming per year.

The results of this study show that the percentage of cows with claw disorders was very farm specific. Optimal welfare housing conditions with a consequent management of animalhuman-relationships improve the status of claw health very well. Cows, which were kept on solid concrete floors with deep bedded cubicles, had a lower risk for claw disorders than cows in farms with concrete slatted floors and high cubicles. The functional hoof trimming should be carried out two or better three times per year and all claw disorders should be recorded to get an overview of the cow's claw health. Further researches with more farms and different housing conditions are necessary to analyse and determine the essential herd parameters and their intensity, which cause claw disorders. A good claw health is also very important to increase the efficiency of milk production and improve the acceptance of milk products by the customer.

\section{References}

Alban L (1995) Lameness in Danish dairy cows: frequency and possible risk factors. Prev Vet Med 22, 213-225

Benz B (2007) Walking area for dairy cattle - solutions for animal and technology. Bautagung RaumbergGumpenstein, 23-24 May 2007, Höhere Bundeslehr- und Forschungsanstalt für Landwirtschaft RaumbergGumpenstein, Irdning (A), 63-66 [in German]

Bergsten C (2001) Effects of conformation and management system on hoof and leg diseases and lameness in dairy cows. Food Anim Pr 17, 11-35

Booth CJ, Warnick LD, Gröhn YT, Maizon DO, Guard CL, Janssen D (2004) Effect of lameness on culling in dairy cows. J Dairy Sci 87, 4112-4122

Cook N (2008) Good on foot through more comfort. Elite-Magazin für Milcherzeuger, Issue 5/2008, $48-51$ [in German]

Eilers T (2008) Longtimeobservations to claw health in four dairy cattle farms in northwest Lower Saxony with regards to chosen riskindicators on animal- and herdlevel. PhD Thesis, Free University of Berlin, Germany [in German] 
Fiedler A (2004) Claw disorders - the new diagnosis key. 1. Internationaler Trendreport Klauengesundheit, Deutsche Landwirtschafts-Gesellschaft e.V., DLG-Verlag Frankfurt am Main, Germany [in German]

Hare E, Norman HD, Wright JR (2006) Survival rates and productive herd life of dairy cattle in the United States. J Dairy Sci 89, 3713-3720

Hultgren J (2001) Effects of two stall flooring systems on the behaviour of tied dairy cows. Appl Anim Beh Sci 73, 167-177

Kanswohl N, Sanftleben P, Tobi D, Dibbert R, Hauffe H, Flor J, Blum E (2006) Research Report Nr. 1/13: Analysis and assesment of high- and deep-bedded-cubilces for dairy cattle under working, ethologic, hygienic and economic view. Institut für Tierproduktion, LfA für Landwirtschaft und Fischerei, MecklenburgVorpommern, Germany [in German]

Koberg J, Hofmann H, Irps H, Daenicke R (1989) Cattle health under concrete slatted flooring systems. Der praktische Tierarzt 70, 12-17 [in German]

König S, Landmann D (2007) Possibilities for improving claw health - analysis of claw data. 2. DLG-Report Klauengesundheit, Deutsche Landwirtschafts-Gesellschaft e.V., DLG-Verlag Frankfurt am Main, Germany [in German]

Kremer PV, Nueske S, Scholz AM, Foerster M (2006) Effect of soft flooring in free stalls on milk yield, fat, protein and somatic cell counts in dairy cattle. Arch Tierz 49, 250-258 [in German]

Kremer PV, Nueske S, Scholz AM, Foerster M (2007) Comparison of claw health and milk yield in dairy cows on elastic or concrete flooring. J Dairy Sci 90, 4603-4611

Kremer P (2008) Concrete slatted flooring: Better with rubber? Elite-Magazin für Milcherzeuger, Issue 2/2008, 43-45 [in German]

Manske T (2002) Hoof lesions and lameness in Swedish dairy cattle; prevalence, risk factors, effects of claw trimming and consequences of productivity. PhD Thesis, Swedish University of Agricultural Sciences, Sweden

Manske T, Hultgren J, Bergsten C (2002) The effect of claw trimming on the hoof health of Swedish dairy cattle. Prev Vet Med 54, 113-129

Microsoft (2001a) Microsoft Access 2002

Microsoft (2001b) Microsoft Excel 2002

Mülling C (2004) Horn quality - improving through management of claw disorders. 1. Internationaler Trendreport Klauengesundheit (2004), Deutsche Landwirtschafts-Gesellschaft e.V. (DLG), DLG-Verlag Frankfurt am Main, Germany [in German]

Nds. MELVL=Niedersächsisches Ministerium für Ernährung, Landwirtschaft, Verbraucherschutz und Landesentwicklung (2007), Animal protection guideline for dairy cattle, Germany [in German]

Samel M (2005) Horn growth and claw health of dairy cows kept on rubber mats compared to concrete flooring. PhD Thesis, Tierärztliche Hochschule Hannover, Germany [in German]

Sanftleben P, Knierim U, Herrmann HJ, Müller C, Von Borell E (2007) Critical control points (CCP) in dairy cattle. Züchtungsk 79, 339-362 [in German]

SAS Institute Inc. (2003) SAS version 9.1.3, SAS Institute Inc., Cary, NC, USA

Siebenhaar M, Friedli K, Wechsler B (2007) Lying mats for dairy cattle- how long comfortable? AGRARForschung Nutztiere 14, 62-65 [in German]

Somers JGCJ, Frankena K, Noordhuizen-Stassen EN, Metz JHM (2003) Prevalence of claw disorders in Dutch dairy cows exposed to several floor systems. J Dairy Sci 86, 2082-2093

Stanek C (2005) Disorders of moving. In: Hofmann W (2005) Cattle Diseases. 2nd ed, Ulmer Verlag, Stuttgart, Germany [in German]

Steiger A (2000) Consumer-oriented aspects of the future development. Arch Tierz, Special Issue 43, 28-33

Steiner B, Keck M (2000) Fixed dunging machines in dairy and pig housing. FAT-Berichte Nr. 542 [in German]

Sundrum A, Andersson R, Postler G (1994) Animal welfare index 200, Checklist for assessment of housing systems. Institut für Organischen Landbau, Universität Bonn, Germany [in German] 
Tucker CB, Weary DM, Fraser D (2003) Effects of three types of free-stall surfaces on preferences and stall usage by dairy cows. J Dairy Sci 86, 521-529

VIT (2010) Annual report 2009. Vereinigte Informationssysteme Tierhaltung w. V., Verden [in German]

Vanegas J, Overton M, Berry SL, Sischo WM (2006) Effect of rubber flooring on claw health in lactating dairy cows housed in free-stall barns. J Dairy Sci 89, 4251-4258

Waiblinger S, Knierim U, Winckler C (2001) The development of an epidemiologically based on-farm welfare assessment system for use with dairy cows. Acta Agric Scand, Sect A, Animal Sci Suppl 30, 73-77

Wangler A (2007) Efficiency of a cow. Nutztierpraxis Aktuell 6 Issue 21, 12-13 [in German]

Warnick LD, Janssen D, Guard CL, Gröhn YT (2001) The effect of lameness on milk production in dairy cows. J Dairy Sci 84, 1988-1997

Whay HR, Main DCJ, Green LE, Webster AJF (2002) Farmer perception of lameness prevalence. Proceedings of the 12th International Symposium on Lameness in Ruminants, Orlando, FL, USA, 355-358

Wolf J (2000) Housing of dairy cows with a high milk production. Arch Tierz 43, Special Issue, 51-57

Received 23 September 2010, accepted 9 February 2011.

Corresponding author:

Silke Heinz

email: silke.heinz@uni-rostock.de or silfus@gmx.net

Department of Agricultural Technology and Process Engineering, Faculty of Agricultural and Environmental Sciences, University of Rostock, Justus-v.-Liebig-Weg 8, 18059 Rostock, Germany 